\title{
ANALISIS KONDISI FISIK ATLET CLUB BOLA VOLI PUTRI DI KOTA BENGKULU TAHUN 2020
}

\author{
Pipin Silpina $^{1}$, Tono Sugihartono ${ }^{2}$, Ari Sutisyana ${ }^{3}$ \\ ${ }^{123}$ Prodi Penjas, FKIP, Universitas Bengkulu, Kota Bengkulu, Indonesia
}

\begin{tabular}{l} 
Info Artikel \\
\hline Sejarah Artikel: \\
Diterima April 2020 \\
Direvisi April 2020 \\
Diterima April 2020 \\
Tersedia online April 2020 \\
\\
Kata kunci: \\
kondisi fisik, atlet klub bola voli \\
putri, bola voli
\end{tabular}

\begin{abstract}
Abstrak
Penelitian ini bertujuan untuk mengetahui kondisi fisik atlet klub bola voli putri di kota bengkulu tahun 2020. Jenis penelitian yang digunakan dalam penelitian ini adalah deskriptif kuantitatif. Sampel pada penelitian ini adalah atlet dari 4 klub di Kota Bengkulu yang berjumlah 40 atlet. Teknik analisis data yang digunakan dalam penelitian ini adalah statistik deskriptif. Hasil analisis data menyatakan bahwa kondisi fisik atlet klub bola voli putri di Kota Bengkulu adalah baik dengan presentase $62,5 \%$. Dengan kategori baik $(62,5 \%)$, kategori kurang $(37,5 \%)$.
\end{abstract}

\begin{abstract}
This study aims to determine the differences in pliometric training of single leg speed hops and double leg speed hops on the ability of squat style long jump in SMA Negeri 08 Bengkulu Utara. The type of research used in this study was quasi-experimental. The sample in this study was students at SMA Negeri 08 Bengkulu Utara which numbered 50 students. The statistical analysis used is the $t$ test. The results of the t-test analysis of the comparison calculation between the final results of the two groups turned out to have a significant difference. The calculation results state that tcount of 3.02 is greater than ttable 2.069 with the level of $\alpha=0.05$, so it can be concluded that there are differences in the influence of the single leg speed hop pliometric exercise and double leg speed hop hops on the ability of squat style long jump.
\end{abstract}




\section{PENDAHULUAN}

Pada era globalisasi saat ini masyarakat Indonesia sudah mulai menyadari bawah pemeliharaan kesehatan sangat mutlak di perlukan selama manusia masih mengkehendaki hidup sehat jasmani dan rohani. Hal ini terbukti masyarakat Indonesia berlomba-lomba melakukan kegiatan jasmani dan rohani, bahkan telah sering menyelenggarakan kompetisi yang bersifat daerah, nasional, bahkan internasional.

Dalam dunia olahraga setiap orang yang menekuni dan menggeluti suatu cabang olahraga biasanya diasumsikan memiliki tubuh dengan kondisi fisik yang baik, karena tanpa hal itu seseorang/atlet akan mengalami kesulitan dalam melakukan aktivitas olahraga yang ditekuninya dan digeluti. Bagi seorang atlet yang menjadikan olahraga sebagai sarana untuk meningkatkan prestasi maka memiliki kebugaran jasmani yang baik adalah mutlak harus dimiliki, tidak terkecuali dalam olahraga khususnya voli. Para atlet harus melakukan latihan-latihan yang telah diprogramkan oleh pelatih agar dapat mencapai target yang telah ditentukan sesuai dengan program latihan itu sendiri. Karena tanpa latihan yang teratur, terukur, dan kontinyu seorang atlet tidak akan bisa berprestasi secara maksimal. Atlet dengan kondisi fisik yang baik akan lebih mudah untuk menerima dan melakukan latihan, baik latihan fisik, teknik, taktik dan mental yang diberikan oleh pelatih (Maharani, 2016: 1).

Dari observasi dan wawancara yang saya lakukan dengan pelatih club bola voli di Kota Bengkulu, belum diketahuinya kondisi fisik atlet, belum adanya tes kondisi fisik selama latihan maupun pertandingan yang di hadapai, dengan begitu perlunya uji tes kondisi fisik agar prestasi atlet club bola voli di
Kota Bengkulu meningkat. Dari hasil tes kondisi fisik tersebut nantinya pelatih akan lebih mudah membuat program latihan fisik atlet yang lebih terarah dan terukur. Berdasarkan uraian diatas, penulis tertarik untuk melakukan penelitian dengan judul "Analisis Kondisi Fisik Atlet Club Bola Voli Putri di Kota Bengkulu Tahun 2020"

\section{METODE}

Menurut Endang Widi Winardi (2011: 4) Penelitian adalah suatu upaya sistematis dalam menemukan, menganalisis dan menafsirkan bukti-bukti empiris untuk memahami gejala atau menemukan jawaban terhadap suatu permasalahan yang terkait dengan gejala itu.

Jenis penelitian ini merupakan penelitian diskriptif kuantitatif. Metode yang digunakan yaitu dengan menggunakan tes kondisi fisik yang bertujuan untuk mengungkapkan suatu apa adanya. Menurut Sugiyono (2016: 2) metode penelitian pada dasarnya merupakan cara ilmiah untuk mendapatkan data dengan tujuan dan kegunaan tertentu. Metode yang digunakan dalam penelitian ini adalah metode survey. Metode survey digunakan untuk mendapatkan data dari tempat tertentu yang alamiah (bukan buatan) dalam pengumpulan data tes dan pengukuran.

\section{HASIL}

Berdasarkan hasil distribusi presentase tes, dapat di simpulkan bahwa kemampuan lari sprint 30 meter pada klub bola voli ARTHA di kategori dalam "baik sekali" 2 orang atau sebesar $20 \%$, kategori "baik" 5 orang atau sebesar (50\%), kategori "cukup" 2 orang atau sebesar $(20 \%)$, kategori "kurang" 1 orang atau 
sebesar (10\%), dan tidak ada pemain yang masuk dalam kategori "sangat kurang" $(0 \%)$. Hal ini menunjukkan bahwa kemampuan lari sprint 30 meter klub bola voli ARTHA berada pada kategori baik dengan persentase terbesar yaitu 50\%.

\section{Berdasarkan hasil distribusi} presentase tes, dapat di simpulkan bahwa kemampuan vertical jump pada klub bola voli ARTHA di kategori dalam "baik sekali" 2 orang atau sebesar $20 \%$, kategori "baik" 3 orang atau sebesar (30\%), kategori "cukup" 5 orang atau sebesar (50\%), dan tidak ada pemain yang masuk dalam kategori "kurang" serta "sangat kurang" yaitu sebesar (0\%). Hal ini menunjukkan bahwa kemampuan vertical jump klub bola voli ARTHA berada pada kategori cukup dengan persentase terbesar yaitu 50\%. Berdasarkan hasil distribusi presentase tes, dapat di simpulkan bahwa kemampuan sit and reach pada klub bola voli ARTHA di kategori dalam "baik sekali" 3 orang atau sebesar 30\%, kategori "baik" 3 orang atau sebesar (30\%), kategori "cukup" 4 orang atau sebesar $(40 \%)$, dan tidak ada pemain yang masuk dalam kategori "kurang" serta "sangat kurang" yaitu sebesar (0\%).Berdasarkan hasil distribusi presentase tes, dapat di simpulkan bahwa kemampuan vertical jump pada klub bola voli ARTHA di kategori dalam "baik sekali" 1 orang atau sebesar $10 \%$, kategori "baik" 5 orang atau sebesar (50\%), kategori "cukup" 4 orang atau sebesar (40\%), dan tidak ada pemain yang masuk dalam kategori "kurang" serta "sangat kurang" yaitu sebesar (0\%).

Berdasarkan hasil distribusi presentase tes, dapat di simpulkan bahwa kemampuan lari sprint 30 meter pada klub bola voli Fortius di kategori dalam "baik sekali" 3 orang atau sebesar 30\%, kategori "baik" 4 orang atau sebesar (40\%), kategori "cukup" 2 orang atau sebesar $(20 \%)$, kategori "kurang" 1 orang atau sebesar (10\%) dan tidak ada pemain yang masuk dalam "sangat kurang" yaitu sebesar $(0 \%)$.

Berdasarkan hasil distribusi presentase tes, dapat di simpulkan bahwa kemampuan vertical jump pada klub bola voli Fortius di kategori dalam "baik sekali" 2 orang atau sebesar $20 \%$, kategori "baik" 2 orang atau sebesar (20\%), kategori "cukup" 5 orang atau sebesar (50\%), kategori "kurang" 1 orang atau sebesar $(10 \%)$ dan tidak ada pemain yang masuk dalam "sangat kurang" yaitu sebesar $(0 \%)$. Berdasarkan hasil distribusi presentase tes, dapat di simpulkan bahwa kemampuan sit and reach pada klub bola voli Fortius di kategori dalam "baik sekali" 4 orang atau sebesar $40 \%$, kategori "baik" 3 orang atau sebesar $(30 \%)$, kategori "cukup" 3 orang atau sebesar (30\%), dan tidak ada pemain yang masuk dalam "kurang" dan "sangat kurang" yaitu sebesar $(0 \%)$.Berdasarkan hasil distribusi presentase tes, dapat di simpulkan bahwa kemampuan MFT pada klub bola voli Fortius di kategori dalam "baik sekali" 0 orang atau sebesar $0 \%$, kategori "baik" 6 orang atau sebesar (60\%), kategori "cukup" 4 orang atau sebesar (40\%), dan tidak ada pemain yang masuk dalam "kurang" dan "sangat kurang" yaitu sebesar $(0 \%)$.

Berdasarkan hasil distribusi presentase tes, dapat di simpulkan bahwa kemampuan lari sprint 30 meter pada klub bola voli TR di kategori dalam "baik sekali" 2 orang atau sebesar $20 \%$, kategori "baik" 5 orang atau sebesar (50\%), kategori "cukup" 3 orang atau sebesar (30\%), dan tidak ada pemain yang masuk dalam kategori "kurang" dan "sangat kurang" yaitu sebesar (0\%) Hasil presentase tes, dapat di simpulkan bahwa kemampuan vertical jump pada klub bola voli TR di kategori dalam "baik sekali" 2 orang atau sebesar $20 \%$, kategori "baik" 5 orang atau sebesar (50\%), kategori 
"cukup" 3 orang atau sebesar (30\%), dan tidak ada pemain yang masuk dalam kategori "kurang" dan "sangat kurang" yaitu sebesar $(0 \%)$

Berdasarkan hasil distribusi presentase tes, dapat di simpulkan bahwa kemampuan sit and reach pada klub bola voli TR di kategori dalam "baik sekali" 2 orang atau sebesar $20 \%$, kategori "baik" 5 orang atau sebesar (50\%), kategori "cukup" 3 orang atau sebesar $(30 \%)$, dan tidak ada pemain yang masuk dalam "kurang" dan "sangat kurang" yaitu sebesar $(0 \%)$. Berdasarkan hasil distribusi presentase tes, dapat di simpulkan bahwa kemampuan MFT pada klub bola voli TR di kategori dalam "baik sekali" 1 orang atau sebesar $10 \%$, kategori "baik" 5 orang atau sebesar (50\%), kategori "cukup" 3 orang atau sebesar (30\%), dan tidak ada pemain yang masuk dalam "kurang" dan "sangat kurang" yaitu sebesar $(0 \%)$. Berdasarkan hasil distribusi presentase tes, dapat di simpulkan bahwa kemampuan lari sprint 30 meter pada klub bola voli BRY di kategori dalam "baik sekali" 2 orang atau sebesar $20 \%$, kategori "baik" 5 orang atau sebesar (50\%), kategori "cukup" 3 orang atau sebesar (30\%), dan tidak ada pemain yang masuk dalam kategori "kurang" dan "sangat kurang" yaitu sebesar $(0 \%)$

Berdasarkan hasil distribusi presentase tes, dapat di simpulkan bahwa kemampuan vertical jump pada klub bola voli BRY di kategori dalam "baik sekali" 2 orang atau sebesar $20 \%$, kategori "baik" 5 orang atau sebesar $(50 \%)$, kategori "cukup" 3 orang atau sebesar $(30 \%)$, dan tidak ada pemain yang masuk dalam kategori "kurang" dan "sangat kurang" yaitu sebesar (0\%). Berdasarkan hasil distribusi presentase tes, dapat di simpulkan bahwa kemampuan sit and reach pada klub bola voli BRY di kategori dalam "baik sekali" 2 orang atau sebesar
$20 \%$, kategori "baik" 5 orang atau sebesar $(50 \%)$, kategori "cukup" 3 orang atau sebesar (30\%), dan tidak ada pemain yang masuk dalam "kurang" dan "sangat kurang" yaitu sebesar $(0 \%)$. Berdasarkan hasil distribusi presentase tes, dapat di simpulkan bahwa kemampuan MFT pada klub bola voli BRY di kategori dalam "baik sekali" 1 orang atau sebesar $10 \%$, kategori "baik" 6 orang atau sebesar $(60 \%)$, kategori "cukup" 3 orang atau sebesar (30\%), dan tidak ada pemain yang masuk dalam "kurang" dan "sangat kurang" yaitu sebesar $(0 \%)$.

\section{PEMBAHASAN}

Dari deskripsi di atas terlihat bahwa kemampuan fisik kecepatan mayoritas pada kategori baik. Kecepatan memberikan pengaruh dalam pergerakan dan dengan kecepatan yang baik atlet juga dapat mengambil keputus secara cepat dan cermat disaat pertandingan maupun proses latihan. Latihan kecepatan perlu ditambahkan guna peningkatan Kemampuan fisik tersebut. Power tungkai memberikan pengaruh yang cukup penting di permainan bola voli. Menurut Albertus Fenanlampir dan Muhammad (2015: 223) mengatakan komponenkomponen fisik dasar yang diperlukan olahraga bola voli adalah daya ledak dengan semakin bagusnya daya ledak seseorang atlet maka semakin bagus juga kecepatan untuk melakukan lompatan, daya ledak yang dimaksud adalah power otot tungkai. Latihan power tungkai dapat dilakukan dengan latihan plyometric mampu dimanfaatkan dengan baik salah satunya lateral cone hop. Kelenturan tubuh diperlukan oleh atlet bola voli agar dapat melakukan gerakan secara optimal. Sebagai contoh, pada saat melakukan salah satu teknik bola voli diperlukan kelenturan tubuh untuk dapat melakukan gerakan yang benar dan tepat 
Apabila dilihat dari frekuensi tiap kategori, terlihat bahwa kemampuan daya tahan atlet bola voli putri di Kota Bengkulu tahun 2020 mayoritas pada kategori baik. Pelatih perlu memberikan progam latihan fisik dengan peningkatan menu latihan secara rutin. Selanjutnya untuk meningkatkan kondisi fisik sedikit memberikan Variasi latihan yang diperlukan untuk peningkatan daya tahan dan mengurangi kejenuhan atlet terhadap porsi latihan yang berat. Sehingga pada saat tes hasil latihan memberikan pengaruh peningkatan pada atlet

\section{SIMPULAN}

Berdasarkan hasil penelitian dan pembahasan yang telah diuraikan pada bab sebelumnya, dapat disimpulkan bahwa kondisi fisik atlet klub bola voli putri di Kota Bengkulu adalah baik dengan presentase sebesar $62,5 \%$.

\section{DAFTAR PUSTAKA}

Candrawati, Y., \& Ilahi, B. R. (2018). Evaluasi Program Pembinaan Prestasi Olahraga Bola Voli Pada Smk Negeri Di Kota Bengkulu. Kinestetik, 2(1), 44-48.

Edwan, E., Sutisyana, A., \& Restu Ilahi, B. (2017). Pengaruh metode latihan plyometric terhadap kemampuan jumping smash bola voli siswa ekstrakurikuler SMPN 1 bermani ilir Kabupaten Kepahiang. Jurnal Kinestetik : Jurnal Ilmiah Pendidikan Jasmani, 1(1), 67-70. doi: $10.33369 /$ jk.v1i1.3380

Fenanlampir, A dan Muhammad, M.F 2015. Tes dan Pengukuran dalam Olahraga. Yogyakarta: CV Andi Offset.

Garciana, M. (2019). Pengaruh Latihan Memukul Bola Gantung Terhadap Kemampuan Jump Service Atlet
Putra Club Caroline Kota Lubuklinggau Provinsi Sumatera Selatan. Kinestetik, 3(1), 57-62. Maharani, L.W. 2016. Profil Kemampuan Fisik Porda Kabupaten Gunung kidul 2015. Jurnal Ilmu Keolahragaan, Vol 2 (1) hal. 43-46.

Hasanah, M. (2013). Pengaruh Latihan Pliometrik Depth Jump Dan Jump To Box Terhadap Power Otot Tungkai Pada Atlet Bolavoli Klub Tugumuda Kota Semarang (Doctoral dissertation, Universitas Negeri Semarang).

Ismoko, A. P., \& Sukoco, P. (2013). Pengaruh metode latihan dan koordinasi terhadap power tungkai atlet bola voli junior putri. Jurnal Keolahragaan, 1(1), 1-12.

Saptiani, D., Sugiyanto, S., \& Syafrial, S. (2019). Hubungan kekuatan otot lengan dan koordinasi mata tangan terhadap akurasi servis atas bola voli pada peserta putri ekstrakurikuler di SMAN 2 Seluma. Jurnal Kinestetik : Jurnal Ilmiah Pendidikan Jasmani, 3(1), 42-50. doi: 10.33369/jk.v3i1.8810

Shodiq, A., \& Sugihartono, T. (2019). Pengaruh Latihan Lompat Gawang Dalam Meningkatkan Tinggi Lompatan Spike Pada Permainan Bola Voli Siswa Ekstrakurikuler Di Man 2 Kota Bengkulu. Kinestetik, 3(1), 29-33.

Sugihartono, T., \& Pujianto, D. (2019). Upaya Meningkatkan Kemampuan Servis Atas Melalui Penerapan Latihan Menggunakan Dumbbell Pada Siswa Kelas X Ips 6 Sma Plus Negeri 7 Bengkulu. Kinestetik, 3(1), 125-131.

Sukadiyanto. 2002. Pengantar Teori dan Metodologi Melatih Fisik. Universitas Negeri Yogyakarta: Fakultas Ilmu 
Keolahragaan.

Sugiyono. 2016. Metode Penelitian Pendidikan Pendekatan Kuantitatif, Kualitatif, Rdan D. Bandung : Alfabet

Sutisyana, A., \& Ilahi, B. R. (2017). Pengaruh Metode Latihan Plyometric Terhadap Kemampuan Jumping Smash Bola Voli Siswa Ekstrakurikuler Smpn 1 Bermani Ilir Kabupaten Kepahiang. Kinestetik, 1(1).

Uliyandari, A. (2009). Pengaruh latihan fisik terprogram terhadap perubahan nilai konsumsi oksigen maksimal (VO2Max) pada siswi sekolah bola voli tugu muda Semarang usia 11-13 tahun (Doctoral dissertation, Medical faculty).

Wicaksono, D. (2009). Pengaruh kepercayaan diri, motivasi belajar sebagai akibat dari latihan bola voli terhadap prestasi belajar atlet di sekolah. Yogyakarta: Universitas Negeri Yogyakarta.

Yudiana, Y. (2015). Implementasi Model Pendekatan Taktik dan Teknik dalam Pembelajaran Permainan Bola Voli pada Pendidikan Jasmani Siswa Sekolah Menengah Pertama. ATIKAN, $5(1)$. 